\title{
PERBAIKAN KUALITAS PAKAN DAN KINERJA PERTUMBUHAN IKAN NILA DENGAN PENAMBAHAN ENZIM PROTEASE BAKTERI PADA PAKAN FORMULASI
}

\author{
Titin Kurniasih"), Nur Bambang Priyo Utomo"*), Zafril Imran Azwar ${ }^{* * *}$, \\ Mulyasari"), dan Irma Melati*) \\ *) Balai Penelitian dan Pengembangan Budidaya Air Tawar \\ Jl. Sempur No. 1, Bogor 16154 \\ E-mail: titink2008@yahoo.com \\ *) Fakultas Perikanan dan IImu Kelautan, Institut Pertanian Bogor \\ Jl. Lingkar Akademik, Kampus IPB Darmaga, Bogor 16680 \\ ***) Pusat Penelitian dan Pengembangan Perikanan Budidaya \\ Jl. Ragunan 20, Pasar Minggu, Jakarta Selatan 12540
}

(Naskah diterima: 26 November 2012; Disetujui publikasi: 19 Februari 2013)

\begin{abstract}
ABSTRAK
Penelitian ini bertujuan menguji pengaruh pemberian enzim protease bakteri pada pakan formulasi terhadap kecernaan nutrien, efisiensi pakan, dan pertumbuhan ikan nila. Penelitian menggunakan rancangan acak lengkap (RAL) dengan lima perlakuan dan tiga ulangan, yaitu pakan formulasi kontrol tanpa penambahan enzim (FK 28), pakan formulasi yang ditambah enzim protease yang diproduksi oleh bakteri Bacillus cereus $(\mathrm{FBC})$, pakan formulasi yang diberi enzim protease yang diproduksi oleh bakteri Staphylococcus epidermidis (FSe), pakan komersial berkadar protein 28\% (KK 28), dan pakan komersial berkadar protein 31\% (KK 31). Penelitian menggunakan ikan nila berukuran awal $4,07 \pm 0,25 \mathrm{~g}$, dilakukan pada 15 buah akuarium berukuran $60 \mathrm{~cm} \times 50$ $\mathrm{cm} \times 50 \mathrm{~cm}$ yang dilengkapi sistem resirkulasi selama enam puluh hari pengamatan. Hasil penelitian menunjukkan bahwa pemberian enzim protease bakteri Bacillus cereus secara signifikan mampu meningkatkan efisiensi pakan dan pertumbuhan ikan nila dibandingkan dengan pakan kontrol. Kecernaan protein dan total pakan meningkat secara signifikan dengan adanya penambahan enzim protease bakteri Staphylococcus epidermidis dan Bacillus cereus. Penambahan enzim bakteri Staphylococcus epidermidis dan Bacillus cereus juga secara nyata meningkatkan retensi protein dan palatabilitas pakan formulasi. Sintasan tidak berbeda nyata di antara kelima perlakuan. Diperoleh kesimpulan bahwa enzim protease kedua bakteri tersebut efektif untuk meningkatkan kualitas pakan dan kinerja pertumbuhan ikan nila.
\end{abstract}

KATA KUNCl: enzim protease, kinerja pertumbuhan, kecernaan nutrien, efisiensi pakan, ikan nila

ABSTRACT: The improvement of feed quality and growth performance of nile tilapia using the addition of bacterial protease to formulated feed. By: Titin Kurniasih, Nur Bambang Priyo Utomo, Zafril Imran Azwar, Mulyasari, and Irma Melati

This research aimed to evaluate the effect of supplementation of bacterial protease to formulated feed on nutrient digestibility, feed efficiency, and growth performance of nile tilapia. A sixty days feeding study was conducted using 5 treatments with 3 replicate groups of nile tilapia (average weight of $4.07 \pm 0.25 \mathrm{~g}$ ), reared on 15 aquarias 
sized of $60 \mathrm{~cm} \times 50 \mathrm{~cm} \times 50 \mathrm{~cm}$ which is equipped with a resirculation system. The treatments were a feeding trial using enzyme treated feeds as follows: formulated feed containing protein level of $28 \%$ without any enzyme addition (FK 28), the same formulated feed with an addition of Bacillus cereus protease ( $F B C$ ), the same formulated feed with an addition of Staphylococcus epidermidis protease (FSe), commercial feed with protein content of $28 \%$ (KK 28) and commercial feed with protein content of $31 \%$ (KK 31). Results showed that the addition of Bacillus cereus protease gave a significant increase on feed efficiency and growth performance of nile tilapia. The addition of Staphylococcus epidermidis and Bacillus cereus protease gave a significant increase on apparent digestibility of dry matter and crude protein, protein retention, and feed consumption of nile tilapia. Fish survival was not different among the seven treatments. This result suggested that bacterial protease was effective in improving feed quality and growth performance of nile tilapia.

\section{KEYWORDS: protease, growth performance, nutrient digestibility, feed efficiency, nile tilapia}

\section{PENDAHULUAN}

Pakan adalah komponen biaya terbesar yang dikeluarkan dalam kegiatan operasional budidaya perikanan. Meningkatnya harga pakan ikan tanpa disertai kenaikan harga jual ikan hasil budidaya adalah permasalahan yang dihadapi setiap pembudidaya ikan saat ini. Tingginya harga pakan ikan terutama disebabkan oleh tingginya harga bahan baku sumber protein pakan yang sejauh ini masih didominasi oleh tepung ikan, dan tingginya kandungan protein yang diperlukan dalam formulasinya (Gatlin III et al., 2007). Oleh karena itu, upaya pencarian bahan baku sumber protein alternatif yang dapat mengurangi tingkat inklusi tepung ikan harus giat dilakukan.

Berbagai jenis bahan baku sumber protein alternatif sudah dikaji, misalnya tepung bungkil kedelai (Saidy \& Gaber, 2002) dan tepung darah (Johnson \& Summerfelt, 2000). Bahan baku alternatif ini diharapkan ketersediaannya cukup, kontinu, mudah didapat dan harganya murah. Tepung darah misalnya, memiliki kandungan protein cukup tinggi hingga 92\% (Johnson \& Summerfelt, 2000), sedangkan tepung bungkil kedelai hingga $48 \%$ (Li et al., 2000). Namun kecernaan total dan kecernaan protein kedua bahan baku ini masih perlu ditingkatkan. Koefisien kecernaan protein tepung ikan, tepung darah, dan tepung bungkil kedelai untuk ikan kerapu bebek (Cromileptes altivelis) berturut-turut adalah 82,4\%; 67,2\%; dan 55,2\% (Laining et al., 2003).

Tingkat kecernaan suatu bahan dapat ditingkatkan dengan penambahan enzim pada pakan benih ikan bandeng (Aslamyah, 2006), ikan gurami (Rosmawati, 2005; Hasan, 2000) dan ikan gilthead seabream (Kolkovski et al., 1993), salah satunya adalah enzim protease (Rosmawati, 2005). Enzim protease disekresikan oleh mikrob proteolitik yang mampu menghidrolisis protein kompleks menjadi protein sederhana sehingga lebih mudah diserap dan dimanfaatkan ikan.

Bakteri yang terdapat di dalam saluran pencernaan ikan diketahui dapat memberikan manfaat untuk meningkatkan aktivitas pencernaan ikan, karena kemampuannya mensekresikan berbagai jenis enzim. Penelitian bakteri pada saluran pencernaan ikan telah banyak dilaporkan (Clarke \& Bauchop, 1977; Das \& Tripathi, 1991; Nakayama et al., 1994; Cai et al., 1998; Aslamyah, 2006; Ghanbari et al., 2009. Nopitawati, 2010 ; Sabariah, 2010; Putra, 2010). Walaupun demikian, informasi mengenai peranannya sebagai sumber enzim pencernaan untuk pakan ikan dan aplikasinya untuk predigestion masih sangat terbatas, khususnya di Indonesia. Berdasarkan informasi di atas, maka telah dilakukan suatu penelitian isolasi mikroba proteolitik dari saluran pencernaan ikan lele, dan diperoleh dua kandidat bakteri proteolitik (Kurniasih et al., 2012). Penelitian ini bertujuan untuk menguji pengaruh penambahan enzim protease yang diproduksi oleh bakteri Staphylococcus epidermidis dan Bacillus cereus hasil isolasi terhadap kualitas pakan formulasi dan kinerja pertumbuhan ikan nila.

\section{BAHAN DAN METODE}

Pakan yang digunakan dalam penelitian ini adalah pakan buatan (formulasi). Komposisi bahan pakan formulasi dan hasil analisis proksimat pakan penelitian tersaji pada Tabel 1 . 
Tabel 1. Komposisi pakan penelitian dan proksimatnya

Table 1. Diet formulation and proximat composition of experimental feed

\begin{tabular}{|c|c|c|c|c|}
\hline \multirow{2}{*}{$\begin{array}{c}\text { Bahan } \\
\text { Ingredients }\end{array}$} & \multirow{2}{*}{$\begin{array}{c}\text { Persentase } \\
\text { (\% bobot } \\
\text { kering) } \\
\text { Percentage } \\
\text { (\% dry matter) }\end{array}$} & \multicolumn{3}{|c|}{$\begin{array}{l}\text { Komposisi proksimat pakan formulasi } \\
\text { Proximate composition of the formulated feed (\%) }\end{array}$} \\
\hline & & $\begin{array}{l}\text { Nut rien } \\
\text { Nut rients }\end{array}$ & $\begin{array}{l}\text { Basah } \\
\text { Wet }\end{array}$ & $\begin{array}{l}\text { Kering } \\
\text { Dry }\end{array}$ \\
\hline Tepung ikan (Fish meal) & 10.00 & Protein (Crude protein) & 28.00 & 31.12 \\
\hline $\begin{array}{l}\text { Tepung bungkil kedelai } \\
\text { Soy bean meal }\end{array}$ & 20.77 & Lemak (Crude lipid) & 7.29 & 8.10 \\
\hline $\begin{array}{l}\text { Tepung darah } \\
\text { Blood meal }\end{array}$ & 6.13 & Serat kasar (Fibre) & 6.03 & 6.71 \\
\hline Dedak (Rice meal) & 19.78 & Abu (Ash) & 9.15 & 10.17 \\
\hline Polar (Pollard) & 34.62 & BETN (NFE) & 39.50 & 43.90 \\
\hline Minyak ikan (Oil fish) & 2.12 & Air (Water) & 10.03 & 0.00 \\
\hline Minyak jagung (Corn oil) & 2.97 & \multicolumn{2}{|c|}{$\begin{array}{c}\text { Kalori/Protein } \\
\text { CP rasio (kkal/g protein) } \\
\text { Calori/Protein } \\
\text { Ratio CP (kcal/g protein) }\end{array}$} & 9.14 \\
\hline$\frac{\text { CMC }}{\text { Jumlah (Total) }}$ & $\frac{1.49}{100.00}$ & \multicolumn{2}{|c|}{$\begin{array}{c}\mathrm{DE}(\mathrm{kkal} / \mathrm{kg}) \\
\text { Digestible energy (kcal/kg) }\end{array}$} & $2,842.99$ \\
\hline
\end{tabular}

Sumber (Source): NRC (1977)

Keterangan (Note):

Total energi tercerna (DE) dihitung berdasarkan: protein 3,5 kkal; lemak 8,1 kkal; BETN 2,5 kkal (Digestible energy was calculated based on: protein $3.5 \mathrm{kcal}$; lipid $8.1 \mathrm{kcal}$; NFE (Nitrogen free extract) $2.5 \mathrm{kcal}$ )

Enzim yang diberikan pada pakan percobaan adalah enzim produksi bakteri Staphylococcus epidermidis dan Bacillus cereus, dengan dosis $1.000 \mathrm{~mL} / \mathrm{kg}$ pakan (Fitriliyani, 2010; Kurniasih et al., 2012). Kedua bakteri merupakan isolat milik Balai Penelitian dan Pengembangan Budidaya Air Tawar, Bogor. Produksi enzim kasar mengacu pada metode yang dilakukan Wang et al. (2008), dengan modifikasi pada suhu dan pengenceran media yang digunakan. Kultur bakteri Staphylococcus epidermidis dan Bacillus cereus masingmasing sebanyak $1.000 \mathrm{~mL}$ disiapkan dengan cara menumbuhkan $10 \mathrm{~mL}$ sumber inokulum cair bakteri dalam $990 \mathrm{~mL}$ TSB baru dan diinkubasi selama 72 jam pada suhu $37^{\circ} \mathrm{C}$. Homogenisasi dengan vortex dilakukan sesering mungkin selama inkubasi ini. Setelah inkubasi, kultur bakteri ini selanjutnya disentrifus dengan kecepatan $12.000 \mathrm{rpm}$ pada suhu $4^{\circ} \mathrm{C}$ selama 20 menit. Supernatan diambil dan ditambah dengan ammonium sulfat (608 $\mathrm{g} / \mathrm{L}$ ), disimpan semalam pada suhu $4^{\circ} \mathrm{C}$, dan disentrifus kembali pada kecepatan 12.000 rpm pada suhu $4^{\circ} \mathrm{C}$ selama 20 menit. Endapan yang terbentuk diambil dan dilarutkan kembali dalam $50 \mathrm{~mL}$ buffer fosfat $50 \mathrm{mM} \mathrm{pH} \mathrm{7.} \mathrm{Larutan}$ buffer berisi endapan inilah yang dimaksudkan sebagai cairan enzim sebanyak $1.000 \mathrm{~mL}$, karena diproses dari kultur bakteri sebanyak $1.000 \mathrm{~mL}$.

Cairan enzim sebanyak $1.000 \mathrm{~mL}$ dituangkan ke dalam $1 \mathrm{~kg}$ campuran bahan baku pakan yang sudah dihaluskan dan diaduk merata. Inkubasi enzim terhadap pakan dilakukan pada suhu kamar selama 24 jam (Fitriliyani et al., 2010; Kurniasih et al., 2012).

Rancangan dalam penelitian ini adalah rancangan acak lengkap (RAL) dengan perlakuan sebagai berikut:

A. Pakan formulasi kontrol dengan kadar protein 28\% (FK 28)

B. Pakan formulasi yang ditambah enzim dari bakteri Bacillus cereus (FBc) 
C. Pakan formulasi yang ditambah enzim dari bakteri Staphylococcus epidermidis (FSe)

D. Pakan komersial kontrol berkadar protein $28 \%$ (KK 28)

E. Pakan komersial kontrol berkadar protein $31 \%(\mathrm{KK} 31)$

Ikan nila dengan bobot rata-rata 4,07 $\pm 0,25$ g ditebar dengan kepadatan 10 ekor/akuarium. Wadah yang digunakan adalah akuarium berukuran $60 \mathrm{~cm} \times 50 \mathrm{~cm} \times 50 \mathrm{~cm}$ sebanyak 15 buah, yang masing-masing diisi air bervolume $90 \mathrm{~L}$ dan dilengkapi sistem resirkulasi dan menggunakan tandon air. Pengaturan dan penempatan wadah perlakuan dilakukan secara acak dengan menggunakan bilangan acak (Steel \& Torrie, 1995).

Pemberian pakan dilakukan 3 kali sehari sebanyak $5 \%$ dari bobot biomassa ikan nila/ akuarium/hari. Pemantauan bobot biomassa ikan uji dilakukan dengan sampling setiap 15 hari sekali. Jumlah pakan yang diberikan dicatat untuk mendapatkan data konsumsi pakan, efisiensi pakan, dan retensi protein. Penelitian pertumbuhan ini dilakukan selama 60 hari.

Penggantian air di tandon filter dilakukan setiap 3 hari sekali, dan penyiponan kotoran dilakukan setiap hari. Pengukuran kualitas air dilakukan pada awal, hari ke-30 dan akhir masa pemeliharaan meliputi: suhu, $\mathrm{pH}$, oksigen terlarut, dan amonia.

Parameter kinerja pertumbuhan dan kesehatan ikan yang diamati adalah:

\section{Laju Pertumbuhan Spesifik (LPS)}

Laju pertumbuhan spesifik ikan uji dihitung mengikuti rumus yang digunakan oleh Mundheim et al. (2004) yaitu:

$$
\text { LPS }=\frac{\ln W t-\ln W_{0}}{T} \times 100 \%
$$

di mana:

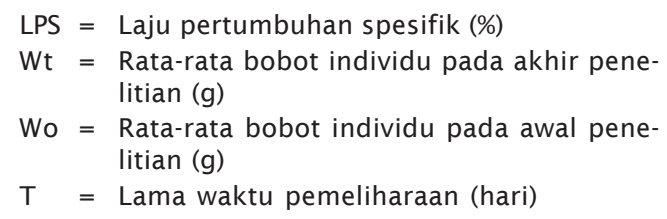

\section{Jumlah Konsumsi Pakan}

Jumlah pakan yang dikonsumsi ikan uji dihitung dengan cara menimbang pakan yang diberikan setiap hari, dan juga pakan yang tersisa setiap hari sebagai pengurangnya. Jumlah keseluruhan pakan yang dikonsumsi pada setiap unit penelitian selama 60 hari dicatat sebagai data jumlah konsumsi pakan.

\section{Retensi Protein}

Nilai retensi protein dihitung berdasarkan persamaan Takeuchi (1988) sebagai berikut:

$$
R P=[(F-I) / P] \times 100 \%
$$

di mana:

$\mathrm{RP}=$ Retensi protein (\%)

$\mathrm{F}=$ Jumlah protein tubuh ikan pada akhir penelitian $(\mathrm{g})$

$\mathrm{I}$ = Jumlah protein tubuh ikan pada awal penelitian (g)

$\mathrm{P}=$ Jumlah protein yang dikonsumsi ikan $(\mathrm{g})$

\section{Efisiensi Pakan}

Perhitungan efisiensi pakan didasarkan pada NRC (1977), yaitu besarnya rasio perbandingan antara pertambahan bobot ikan yang didapatkan dengan jumlah pakan yang dikonsumsi ikan. Semakin besar nilai pertambahan bobot maka efisiensi pakan semakin besar.

$$
E P=\frac{(W t+D)-W o}{J K P} \times 100 \%
$$

di mana:

$E P=$ Efisiensi pakan (\%)

$\mathrm{Wt}=$ Biomassa ikan pada akhir pemeliharaan $(\mathrm{g})$

$W_{0}=$ Biomassa ikan pada awal pemeliharaan $(\mathrm{g})$

$\mathrm{D}=$ Bobot ikan yang mati selama penelitian $(\mathrm{g})$

$\mathrm{JKP}=$ Jumlah pakan yang diberikan selama penelitian (g)

\section{Sintasan}

Sintasan menggambarkan kesehatan ikan dan dihitung berdasarkan persamaan yang dikemukakan oleh Huisman (1987) yaitu:

$$
\mathrm{SR}=\mathrm{Nt} / \mathrm{No} \times 100 \%
$$

di mana:

$\mathrm{SR}=$ Sintasan (\%)

$\mathrm{Nt}=$ Jumlah pada akhir penelitian (ekor)

No =Jumlah pada awal penelitian (ekor)

Pengujian daya cerna pakan oleh ikan nila dilakukan secara terpisah dari uji pertumbuhan. Hal ini dimaksudkan agar kegiatan pengumpulan feses tidak mengganggu pertumbuhan ikan uji. Akuarium yang digunakan 
untuk uji kecernaan berukuran lebih besar, yaitu $100 \mathrm{~cm} \times 60 \mathrm{~cm} \times 50 \mathrm{~cm}$ sebanyak 15 buah.

Pembuatan pakan penelitian untuk uji kecernaan dilakukan sama seperti pakan untuk uji pertumbuhan, namun ditambahkan 0,6\% $\mathrm{Cr}_{2} \mathrm{O}_{3}$ sebagai indikator kecernaan. Pakan diberikan pada ikan selama 3 minggu dan pengumpulan feses mulai dilakukan pada hari ketujuh dengan cara menyedot feses di dasar akuarium dengan selang kecil dan ditampung di ember. Selanjutnya feses yang mengendap di dasar ember disaring dan dikumpulkan dalam botol film. Feses yang terkumpul dikeringkan dalam oven bersuhu $110^{\circ} \mathrm{C}$ selama 4-6 jam, dan dianalisis kandungan $\mathrm{Cr}_{2} \mathrm{O}_{3}$ dan kadar proteinnya.

Penghitungan nilai kecernaan berdasarkan Takeuchi (1988):

$$
\begin{gathered}
\mathrm{KT}=100 \times\left(1-\left(\mathrm{b} / \mathrm{b}^{\prime}\right)\right. \\
\mathrm{KP}=100 \times\left[\left(1-\left(\mathrm{a}^{\prime} / \mathrm{a} \times \mathrm{bb}^{\prime}\right)\right]\right.
\end{gathered}
$$

di mana:

$\mathrm{KT}=$ Kecernaan total (\%)

$$
\begin{aligned}
\mathrm{KP}= & \text { Kecernaan protein }(\%) \\
\mathrm{a}= & \text { Kadar nutrien (protein) dalam pakan (bobot } \\
& \text { kering) } \\
\mathrm{a}^{\prime}= & \text { Kadar nutrien (protein) dalam feses (bobot } \\
& \text { kering) } \\
\mathrm{b}= & \text { Kadar indikator } \mathrm{Cr}_{2} \mathrm{O}_{3} \text { dalam pakan (\% bobot } \\
& \text { kering) } \\
\mathrm{b}^{\prime}= & \begin{array}{l}
\text { Kadar indikator } \mathrm{Cr}_{2} \mathrm{O}_{3} \text { dalam feses }(\% \text { bobot } \\
\text { kering) }
\end{array}
\end{aligned}
$$

Data hasil uji pertumbuhan (LPS), konsumsi pakan (JKP), efisiensi pakan (EP), retensi protein (RP) pakan, retensi lemak (RL) pakan, kecernaan pakan total (KT), kecernaan protein pakan (KP), dan sintasan (SR) dianalisis secara statistika dengan Anova dan uji Duncan dengan selang kepercayaan $95 \%$.

\section{HASIL DAN BAHASAN}

Hasil uji kecernaan total dan protein pakan disajikan di Tabel 2. Pakan formulasi yang ditambah enzim bakteri Bacillus cereus (FBc)

\begin{tabular}{|c|c|c|c|c|c|}
\hline \multirow{4}{*}{$\begin{array}{l}\text { Parameter } \\
\text { Parameters }\end{array}$} & \multicolumn{3}{|c|}{$\begin{array}{l}\text { Pakan formulasi } \\
\text { Formulated feed ( } 28 \% \text { prot ein) }\end{array}$} & \multicolumn{2}{|c|}{$\begin{array}{l}\text { Pakan komersial } \\
\text { Commercial feed }\end{array}$} \\
\hline & \multirow{2}{*}{$\begin{array}{l}\text { Kont rol } \\
\text { Control }\end{array}$} & \multicolumn{2}{|c|}{$\begin{array}{l}\text { Enzim } \\
\text { Enzyme }\end{array}$} & \multirow[t]{2}{*}{$\begin{array}{l}28 \% \text { protein } \\
\text { Prot ein } 28 \%\end{array}$} & \multirow[t]{2}{*}{$\begin{array}{l}31 \% \text { protein } \\
\text { Protein } 31 \%\end{array}$} \\
\hline & & B. cereus & S. epidermidis & & \\
\hline & FK 28 & FBC & FSe & KK 28 & KK 31 \\
\hline KT (\%) & $48.41 \pm 1.62^{\mathrm{a}}$ & $71.97 \pm 1.83^{d}$ & $75.95 \pm 0.76^{e}$ & $60.77 \pm 0.86^{b}$ & $69.59 \pm 0.49^{c}$ \\
\hline KP (\%) & $74.85 \pm 1.01^{\mathrm{a}}$ & $83.80 \pm 0.08^{d}$ & $90.20 \pm 0.31^{\mathrm{e}}$ & $75.14 \pm 0.54^{\mathrm{a}}$ & $82.20 \pm 1.42^{c}$ \\
\hline LPS (\%) & $2.33 \pm 0.18^{a}$ & $2.75 \pm 0.18^{\mathrm{bc}}$ & $2.66 \pm 0.08^{a b c}$ & $2.47 \pm 0.09^{a b}$ & $3.01 \pm 0.29^{c}$ \\
\hline$J K P(g)$ & $162.16 \pm 24.82^{\mathrm{a}}$ & $208.74 \pm 31.97 \mathrm{abc}$ & $202.55 \pm 11.24 \mathrm{abc}$ & $184 \pm 17^{\mathrm{abc}}$ & $245.22 \pm 57.68^{c}$ \\
\hline EP (\%) & $75.92 \pm 3.36^{\mathrm{a}}$ & $82.68 \pm 2.67^{\mathrm{bc}}$ & $79.72 \pm 2.45^{\mathrm{ab}}$ & $76.18 \pm 3.24^{\mathrm{a}}$ & $85.77 \pm 3.22^{c}$ \\
\hline RP (\%) & $44.40 \pm 2.03^{a}$ & $49.69 \pm 1.90^{c}$ & $48.50 \pm 1.37^{\mathrm{bc}}$ & $45.41 \pm 2.04^{a b}$ & $44.55 \pm 2.05^{\mathrm{a}}$ \\
\hline SR (\%) & $96.7 \pm 5.8^{a}$ & $96.7 \pm 5.8^{a}$ & $100.0 \pm 0.0^{\mathrm{a}}$ & $100.0 \pm 0.0^{\mathrm{a}}$ & $100.0 \pm 0.0^{\mathrm{a}}$ \\
\hline
\end{tabular}
dan enzim bakteri Streptococcus epidermidis (FSe) meningkat nilai kecernaan protein dan totalnya secara signifikan dibandingkan kontrolnya (FK 28), dengan nilai kecernaan

Tabel 2. Kecernaan total pakan (KT), kecernaan protein pakan (KP), laju pertumbuhan spesifik (LPS), jumlah konsumsi pakan (JKP), efisiensi pakan (EP), retensi protein (RP), dan sintasan (SR) ikan uji

Table 2. Apparent digestibility of dry matter (KT), apparent digestibility of protein feed (KP), spesific growth rate (LPS), feed intake (JKP), feed efficiency (EP), protein retention (RP), and survival rate of the test fish (SR)

Keterangan (Note):

Angka pada baris yang sama yang diikuti huruf superscript yang sama menunjukkan perbedaan yang tidak nyata $(P>0,05)$ antar perlakuan (The values in the same row under the same superscript indicate no significant difference $(P>0.05))$ 
total 48,41\%; 72,97\%; dan 75,95\%; dan kecernaan protein pakan $74,85 \% ; 83,80 \%$; dan 90,20\%; berturut-turut untuk pakan FK 28, FBc, dan FSe. Pakan FBc dan FSe telah mengalami proses pencernaan awal dengan cukup baik disebabkan oleh adanya hidrolisis dengan enzim protease bakteri, sehingga jumlah nutrien terhidrolisisnya lebih banyak dibandingkan pakan FK 28, dan kecernaannya meningkat.

Di antara tiga jenis pakan yang tidak dihidrolisis dengan enzim yaitu, pakan FK 28 memiliki kecernaan total yang paling rendah (48,41\%) dibandingkan pakan KK 31 (69,59\%) dan pakan KK $28(60,77 \%)$ dengan selisih di antara ketiganya yang signifikan, dan juga kecernaan protein FK 28 paling rendah (74,85\%) dibandingkan KK $28(75,14 \%)$ dan KK $31(82,20 \%)$, dengan selisih antara FK 28 dan KK 31 yang signifikan. Hal ini menunjukkan bahwa kualitas bahan pakan FK 28 secara umum paling rendah dari dua pakan lainnya, dan kualitas bahan sumber protein pakan FK 28 sama dengan pakan KK 28, tetapi lebih buruk dari pakan KK 31. Dari hasil penelitian ini terlihat bahwa enzim protease yang diproduksi oleh kedua mikroba proteolitik yang diberikan dalam bahan baku pakan formulasi mampu meningkatkan kecernaan total dan protein pakan secara signifikan. Ini juga bermakna bahwa kondisi bahan baku yang digunakan dalam pakan formulasi penelitian masih memungkinkan untuk ditingkatkan kualitasnya.

Peningkatan nilai kecernaan total dan protein pada pakan penelitian tidak terlepas dari kontribusi bahan-bahan sumber protein pakan yang mengalami hidrolisis dengan bantuan enzim protease bakteri. Tepung bungkil kedelai (TBK), tepung ikan dan tepung darah sebagai tiga komponen terbesar penyumbang protein dalam pakan formulasi akan mengalami perombakan protein yang signifikan bila dihidrolisis oleh enzim protease. Menurut Laining et al. (2003), tepung darah akan mengalami peningkatan kecernaan total dari $48,1 \%$ menjadi $67,9 \%$ dan $61,7 \%$, dan peningkatan kecernaan protein dari 55,2\% menjadi $87,5 \%$ dan $84,2 \%$ setelah difermentasi dengan asam format dan propionat pada uji kecernaan dengan ikan kerapu bebek (Cromileptes altivelis). Ini membuktikan bahwa nilai kecernaan total dan protein tepung darah dapat ditingkatkan dengan beberapa perlakuan, termasuk dengan hidrolisis oleh enzim protease bakteri Staphylococcus epidermidis dan
Bacillus cereus. Ghazi et al. (2002; 2003) dan Marsman et al. (1997) melaporkan adanya peningkatan kecernaan protein pakan yang berbasis TBK setelah diberi perlakuan dengan enzim protease, untuk ayam broiler. Beal \& Brooks (2001) menggunakan teknik in vitro untuk mengevaluasi kemampuan beberapa jenis enzim protease dalam meningkatkan kecernaan nitrogen TBK, dan menemukan peningkatan sebesar $12 \%$ daripada kontrolnya. Rooke et al. (1998) melaporkan adanya peningkatan konsentrasi asam amino TBK setelah diberi perlakuan dengan enzim protease. Sedangkan tepung ikan, menurut Smith et al. (1995), nilai kecernaan proteinnya masih cukup bervariasi $(75,1 \%-91,7 \%$; tergantung jenis ikan yang digunakan), sehingga masih dapat ditingkatkan kecernaannya dengan enzim protease. Hou et al. (2011) yang menggunakan kompleks enzim protease untuk menghidrolisis limbah ikan yang terdiri atas daging dan tulang buangan melaporkan adanya penurunan yang signifikan terhadap jumlah ikatan peptida. Lebih jauh, Rosmawati (2005) juga melaporkan adanya peningkatan kecernaan total dan protein yang signifikan pada pakan penelitiannya yang dihidrolisis dengan enzim pankreatin dan pepsin.

Nilai kecernaan pakan menggambarkan kinerja pencernaan dan penyerapan pakan yang terjadi di saluran pencernaan ikan. Kecernaan pakan dipengaruhi oleh kemampuan ikan mencerna pakan dan kualitas pakan yang dikonsumsi oleh ikan, yang ditentukan oleh karakter bahan baku penyusunnya. Bahan berserat tinggi sangat sukar dicerna oleh ikan non-herbivora karena kurangnya keberadaan enzim yang dapat memecah dinding sel yang kompleks yang terdapat padanya. Sumber protein nabati diketahui memiliki nilai kecernaan protein yang bervariasi karena adanya struktur sekunder dan tersier pada ikatan protein dan perbedaan komposisi asam aminonya. Selain itu, pakan yang karakternya diketahui dapat melintas cepat di saluran pencernaan ikan akan dicerna secara kurang sempurna, karena singkatnya waktu pemaparan oleh enzim pencernaan (Millamena et al., 2002).

Tabel 2 juga menunjukkan bahwa pemberian enzim Staphylococcus epidermidis dan Bacillus cereus pada pakan berpengaruh nyata terhadap meningkatnya LPS ikan nila. LPS ratarata pada pakan FBc dan pakan FSe adalah 2,75\%\% dan 2,66\%; sedangkan pakan FK 28 hanya $2,33 \%$. Berdasarkan hasil uji lanjut 
Duncan, meskipun hanya pakan FBc yang secara signifikan meningkat dibandingkan pakan FK 28, namun LPS pada pakan FBc dan FSe yang berkadar protein $28 \%$ tidak berbeda nyata dengan pakan komersial kontrol (KK 31) yang berkadar protein $31 \%$ (3,01\%). LPS pakan FK 28 secara statistika jauh lebih kecil daripada pakan KK 31.

Peningkatan LPS ini berkaitan dengan adanya peningkatan yang sangat signifikan untuk parameter kecernaan total dan protein pada pakan formulasi yang dihidrolisis oleh enzim bakteri Staphylococcus epidermidis dan Bacillus cereus. Meningkatnya kecernaan total dan protein menyebabkan meningkat pula asupan nutrisi yang terserap dan dimanfaatkan oleh tubuh ikan dalam proses metabolisme. Penyerapan protein yang lebih baik akan menyebabkan meningkatnya ketersediaan asam amino yang diperlukan untuk pertumbuhan. Meningkatnya tingkat penyerapan nutrisi pakan secara total akan meningkatkan ketersediaan energi, yang selanjutnya akan meningkatkan "efek penghematan protein", sehingga asam amino akan lebih termanfaatkan secara efisien sebagai komponen pembangun tubuh dan bukan sebagai sumber energi.

Jumlah pakan yang dikonsumsi ikan nila dari kelima perlakuan juga mengalami perbedaan (Tabel 2). Meskipun selisihnya belum signifikan, konsumsi pakan FBc dan FSe (208,74 g dan 202,55 g) mengalami peningkatan dibandingkan pakan FK 28 (162,16 g); sehingga nilainya secara statistika menyamai konsumsi pakan komersial KK 31 (245,22 g). Sebagaimana diketahui, konsumsi pakan FK 28 secara signifikan lebih rendah daripada pakan komersial KK 31. Hal ini menunjukkan bahwa enzim protease dari bakteri Staphylococcus epidermidis dan Bacillus cereus juga mampu meningkatkan palatabilitas pakan formulasi. Inkubasi pakan formulasi dengan enzim bakteri Staphylococcus epidermidis dan Bacillus cereus menghasilkan aroma yang kuat seperti aroma terasi, yang menjadi atraktan tambahan bagi ikan yang mengonsumsinya.

Dilihat dari parameter efisiensi pakan, pakan FK 28 berada di posisi terendah $(75,92 \%) ;$ sedangkan pakan komersial KK 31 di posisi tertinggi $(85,77 \%)$ dengan jarak bentangan (multiple range test) yang berbeda sangat nyata (Tabel 2). Perlakuan hidrolisis pakan formulasi dengan enzim Baillus cereus (pakan
$\mathrm{FBC}$ ) mampu meningkatkan efisiensi pakan menjadi $82,68 \%$. Nilai efisiensi pakan FBc secara statistik mampu menyamai pakan KK 31 (86\%). Ini mengindikasikan bahwa peningkatan jumlah konsumsi pada pakan yang dihidrolisis oleh enzim yang diproduksi oleh Staphylococcus epidermidis dan Bacillus cereus diikuti juga dengan peningkatan deposisi bobot badan yang lebih efisien, sehingga nilai efisiensi pakannya meningkat.

Pakan FBc dan FSe memberikan nilai retensi protein yang tertinggi $(49,69 \%$ dan $48,50 \%)$; meningkat signifikan dibandingkan pakan FK 28 (44,40\%); dan berbeda nyata dengan pakan KK 28 (45,41\%) dan pakan KK 31 (44,55\%). Tingginya nilai retensi protein pada pakan FBC dan FSe disebabkan karena meskipun kadar proteinnya lebih rendah $(28,10 \%$ bobot basah) dibandingkan pakan KK 31 (31,00\% bobot basah), namun deposisi protein tubuhnya yang tercermin dari laju pertumbuhannya tidak berbeda nyata. Pemberian enzim bakteri Staphylococcus epidermidis dan Bacillus cereus mampu meningkatkan efisiensi pemanfaatan protein pakan dan pembentukan jaringan tubuh.

Tidak ada perbedaan nyata untuk parameter sintasan, yang mengindikasikan bahwa enzim Staphylococcus epidermidis dan BacilIus cereus tidak berpengaruh terhadap parameter ini (Tabel 2). Dari 10 individu ikan yang dipelihara di setiap unit penelitian, kematian yang terjadi maksimal hanya 1 individu saja. Nilai rata-rata sintasan terendah adalah $96,7 \%$ untuk perlakuan FK 28 dan FBc, sedangkan perlakuan FSe, KK 28, dan KK 31 mencapai $100 \%$. Sintasan yang tinggi juga didukung oleh terjaganya kualitas air media hidup ikan nila (Tabel 3). Sistem resirkulasi, penyiponan feses dan pembersihan bak filter resirkulasi yang rutin dilakukan dan pencahayaan dengan lampu TL telah mampu menjaga kualitas air media tetap stabil dan sesuai untuk mendukung kehidupan ikan nila yang optimal.

\section{KESIMPULAN DAN SARAN}

Pemberian enzim yang diproduksi oleh bakteri Bacillus cereus pada pakan formulasi mampu meningkatkan laju pertumbuhan spesifik dan efisiensi pakan ikan nila, dan penambahan Staphylococcus epidermidis dan Bacillus cereus mampu meningkatkan kecernaan protein dan total, retensi protein dan palatabilitas pakan formulasi untuk ikan nila. 
Tabel 3. Kualitas air media pemeliharaan ikan nila

Table 3. Water quality fluctuations in experimental aquarias containing the nile tilapia

\begin{tabular}{clc}
\hline $\begin{array}{c}\text { Nomor } \\
\text { Number }\end{array}$ & \multicolumn{1}{c}{$\begin{array}{c}\text { Parameter } \\
\text { Parameters }\end{array}$} & $\begin{array}{c}\text { Kisaran } \\
\text { Range }\end{array}$ \\
\hline 1 & $\mathrm{pH}$ (unit) & 7 \\
2 & $\mathrm{DO}$ (Dissolved oxygen) $(\mathrm{mg} / \mathrm{L})$ & $5.5-6.5$ \\
3 & Alkalinitas (Alkalinity) $(\mathrm{mg} / \mathrm{L})$ & $80-100$ \\
4 & Kesadahan $($ Hardness) $(\mathrm{mg} / \mathrm{L})$ & $58-71$ \\
5 & $\mathrm{NH}_{3}($ Ammonia) $(\mathrm{mg} / \mathrm{L})$ & 0.02 \\
\hline
\end{tabular}

\section{UCAPAN TERIMA KASIH}

Ucapan terima kasih yang sebesar-besarnya terhadap DIPA Balai Penelitian dan Pengembangan Budidaya Air Tawar Tahun Anggaran 2010 yang telah membiayai kegiatan penelitian ini.

\section{DAFTAR ACUAN}

Aslamyah, S. 2006. Penggunaan mikroflora saluran pencernaan sebagai probiotik untuk meningkatkan pertumbuhan dan kelangsungan hidup ikan bandeng (Chanos-chanos Forsskal). Disertasi. Program Pasca Sarjana, Institut Pertanian Bogor. $255 \mathrm{hlm}$.

Beal, J.D. \& Brooks, P.H. 2001. The effect of pretreatment with different proteases on the in vitro digestibility of nitrogen in raw soya bean and four different full fat soya bean meals. Recent Advances in Animal Nutrition, 13: 19-27.

Cai. Y., Benno, T., Naskase, Y., \& Tae-Kwang, O. 1998. Specific probiotic characterization of Weisella hellenica DS-12 isolated from flounder intestine. Genet. Microbiol., 44: 311-316.

Clarke, R.T.J. \& Bauchop, T. 1977. Microbial Ecology of the Gut. London, New York, San Francisco. Academic Press, 410 pp.

Das, K.M. \& Tripathi, S.D. 1991. Studies on digestive enzymes of grass carp, Ctenopharyngodon idella Val. Aquaculture, 92: 11-21.

Fitriliyani, I. 2010 . Evaluasi nilai nutrisi tepung daun lamtoro gung (Leucaena leucocephala) terhidrolisis dengan ekstrak enzim cairan rumen domba (Ovis aries) terhadap kinerja pertumbuhan ikan nila (Oreochromis niloticus). Jurnal Akuakultur Indonesia, 9(1): 30-37.
Fitriliyani, I., Harris, E., Mokoginta, I., \& Nahrowi. 2010. Peningkatan kualitas nutrisi tepung daun lamtoro sebagai pakan ikan dengan penambahan ekstrak enzim cairan rumen domba. Berita Biologi, 10(2): 135-142.

Gatlin III, D.M., Barrows, F.T., Brown, P., Dabrowski, K., Gaylord, T.G., Hardy, R.W., Herman, E., Hu, G., Krogdahl, -S., Nelson, R., Overturf, K., Rust, M., Sealey, W., Skonberg, D., Souza, E.J., Stone, D., Wilson, R., \& Wurtele, E. 2007. Expanding the utilization of sustainable plant products in aquafeeds: a review. Aquaculture Research, 38: 551 579.

Ghanbari, M., Rezaei, M., Jami, M., \& Nazari, R.M. 2009. Isolation and characterization of Lactobacillus species from intestinal contents of beluga (Huso huso) and Persian sturgeon (Acipenser persicus). Shiraz University. Iranian Journal of Veterinary Research, 10(2)(27): 152-157.

Ghazi, S., Rooke, J.A., Galbraith, H., \& Bedford, M.D. 2002. The potential for the improvement of the nutritive value of soya bean meal by different proteases in broiler chicks and broiler cockerels. Br. Poult. Sci., 43: 7077.

Ghazi, S., Rooke, J.A., \& Galbraith, H. 2003. Improvement of the nutritive value of soybean meal by protease and alpha-galactosidase treatment in broiler chockerels and broiler chicks. Br. Poult. Sci., 44: 410-418.

Hasan, O.D.S. 2000. Pengaruh pemberian enzim papain dalam pakan buatan terhadap pemanfaatan protein dan pertumbuhan benih ikan gurame (Osphronemus gouramy Lac.). Tesis. Program Pascasarjana, Institut Pertanian Bogor, $57 \mathrm{hlm}$.

Hou, H., Li, B., Zhao, X., Zhang, Z., \& Li, P. 2011. Optimization of enzymatic hydrolysis of 
Alaska Pollock frame for preparing protein hydrolysates with low bitterness. LWT-Food Science and Technology, 44(2): 421-428.

Huisman, E.A. 1987. Principles of Fish Production. Department of Fish Culture and Fisheries, Wageningen Agriculture University, Wageningen, Netherland, $170 \mathrm{pp}$.

Johnson, J.A. \& Summerfelt, R.C. 2000. Spraydried blood cells as partial replacement for fishmeal in diets for rainbow trout Oncorhynchus mykiss. J. of The World Aquac. Soc., 31(1): 96-104.

Kolkovski, S., Tandler, A., Kissil, G.M., \& Gertler, A. 1993. The effect of dietary exogenous digestive enzyme on ingestion, assimilation, growth and survival of GH larvae. Fish Fisiol. and Biochem. 12: 203-209.

Kurniasih, T., Fitriliyani, I., Melati, I., \& Azwar, Z.I. 2012. Pemberian ekstrak enzim kasar dari cairan rumen domba pada tepung bungkil kedelai lokal dan pengaruhnya terhadap pertumbuhan ikan nila. J. Ris. Akuakultur, 7(2): 247-256.

Laining, A., Rachmansyah, Ahmad, T., \& Williams, K. 2003. Apparent digestibility of selected feed ingredients for humpback grouper, Cromileptes altivelis. Aquaculture, 218: 529-538.

Li, M.H., Robinson, E.H., \& Hardy, R.W. 2000. Protein sources for feeds. In Stickney, R. (Ed.) Encyclopedia of Aquaculture. John Wiley and Sons, New York, p. 688-695.

Marsman, G.J.P., Gruppen, H., van der Poel, A.F.B., Kwakkel, R.P., Verstegen, M.W.A., \& Voragen, A.G.J. 1997. The effect of thermal processing and enzyme treatments of soybean meal on growth performance, ileal nutrient digestibilities and chime characteristics in broiler chicks. Poult. Sci., 76(6): 864872.

Millamena, O.M., Coloso, R.M., \& Pascual, F.P. 2002. Nutrition in Tropical Aquaculture, Essentials of Fish Nutrition, Feeds, and Feeding of Tropical Aquatic Species. Southeast Asian Fisheries Development Center. Tigbauan, Iloilo, Philippines, 221 pp.

Mundheim, H., Aksnes, A., \& Hope, B. 2004. Growth, feed efficiency and digestibility in salmon (Salmo salar L.) fed different dietary proportions of vegetable protein sources in combination with two fish meal qualities. Aquaculture, 237: 315-331.

Nakayama, A., Yano, Y., \& Yoshida, K. 1994. New method for isolating Barophiles from intestinal contents of deep sea fishes retrieved from the abyssal zone. Appl. and Environm. Microbiol., 60(1 1): 4,21 0-4,212.

Nopitawati, T. 2010 . Seleksi bakteri probiotik dari saluran pencernaan untuk meningkatkan kinerja pertumbuhan udang vaname Litopenaeus vannamei. Tesis. Sekolah Pascasarjana Institut Pertanian Bogor, Bogor, $63 \mathrm{hlm}$.

National Research Council (NRC). 1977. Nutrient Requirements of Warmwater Fishes. National Academy of Sciences. Washington D.C., 78 pp.

Putra, A.N. 2010. Kajian probiotik, prebiotik, dan sinbiotik untuk meningkatkan kinerja pertumbuhan ikan nila. Tesis. Program Pascasarjana, Institut Pertanian Bogor, 91 $\mathrm{hlm}$.

Rooke, J.A., Slessor, M., Fraser, H., \& Thomson, J.R. 1998. Growth performance and gut function of piglets weaned at four weeks of age and fed protease-treated soyabean meal. Animal Feed Science and Technology, 70: 175-190.

Rosmawati. 2005. Hidrolisis pakan buatan oleh enzim pepsin dan pankreatin untuk meningkatkan daya cerna dan pertumbuhan benih ikan gurami (Osphronemous gouramy Lac). Tesis. Program Pascasarjana, Institut Pertanian Bogor, $45 \mathrm{hlm}$.

Sabariah. 2010 . Seleksi bakteri probiotik dari saluran pencernaan untuk meningkatkan kinerja pertumbuhan ikan jelawat (Leptobarbus hoeveni Blkr). Tesis. Program Pascasarjana, Institut Pertanian Bogor, 44 hlm.

Saidy, D.M.S.D. \& Gaber, M.M.A. 2002. Complete replacement of fish meal by soybean meal with dietary l-lysine supplementation for nile tilapia Oreochromis niloticus (L.) fingerlings. J. of the World Aquac. Soc., 33(3): 297306.

Smith, R.R., Winfree, R.A., Rumsey, G.W., Allred, A., \& Peterson, M. 1995. Apparent digestibility coefficients and metabolizable energy of feed ingredients for rainbow trout Oncorhynchus mykiss. Journal of the World Aquaculture Society, 26(4): 432-437.

Steel, R.G.D. \& Torrie, J.H. 1995. Prinsip dan Prosedur Statistika. PT Gramedia Pustaka Utama. Jakarta, $748 \mathrm{hlm}$.

Takeuchi, T. 1988. Laboratory work, chemical evaluation of dietary nutrients. In Watanabe, T. (Ed.) Fish Nutrition and Mariculture. JICA Textbook the General Aquaculture Course. Department of Aquatic Bio- 
science. Tokyo University of Fisheries, p. 179-233.

Wang, S.L., Yang, C.H., Liang, T.W., \& Yen, Y.H. 2008. Optimization of condition for pro- tease production by Chryseobacterium taenense TK U001. Bioresource Technology, 99: 3,700-3,707. 